\title{
THE EFFECT OF SCAFFOLDING TECHNIQUE ON STUDENTS' WRITING COMPETENCY
}

\author{
Gede Wisnu Mahayasa ${ }^{1}$, Putu Eka Dambayana ${ }^{2}$, A.A. Gede Yudha Paramarta ${ }^{3}$ \\ Program Studi Pendidikan Bahasa Inggris \\ Universitas Pendidikan Ganesha, Singaraja, Indonesia \\ e-mail: gede.wisnu.mahayasa@undiksha.ac.id ${ }^{1}$, ekadambayana@undiksha.ac.id², \\ Yudha.Paramartha@undiksha.ac.id ${ }^{3}$
}

\begin{tabular}{|c|c|c|c|}
\hline (c) () () & \multicolumn{3}{|c|}{$\begin{array}{l}\text { This is an open-access article under the CC BY-SA license. } \\
\text { Copyright } \circledast 2021 \text { by Author. Published by Universitas Pendidikan Ganesha. }\end{array}$} \\
\hline Received : Januar & 2021 & Accepted : May, 2021 & Published : June, 2021 \\
\hline
\end{tabular}

\begin{abstract}
Because of Covid 19 pandemic, learning is done in online mode by using various online learning platform. This study aims at investigating the effect of scaffolding technique on students' writing competency in online learning. To run this research, 60 eleventh grade students of SMAN 1 Sukasada in the academic year 2020/2021 were chosen as the samples. This research applied nonequivalent control group design in which there were two groups compared, namely: scaffolding technique and conventional technique. The data of writing competency were collected by using performance test which were then scored by using analytical scoring rubric. The collected data were then analyzed by using independent sample $t$ test. This research shows that there is no significant effect of Scaffolding technique on students' writing competency with probability value of 0.606 ( $p>0,05)$.
\end{abstract}

Keywords: Scaffolding technique, writing competency, skills

\section{INTRODUCTION}

English is a compulsary subject which should be mastered by students. Based on Curriculum 2013, English is started to be taught in Junior High School until tertiery education. Teaching English is focused on the view that language as a tool of communication (BSNP, 2012). It means that the students should be able to use English to communicate in daily life.

Teaching English fouses on 2 skills, productive and receptive skills (Harmer, 2006). Productive skill is a skill where the students should produce something both oral and written form. This skill is like speaking and writing. Meanwhile, receptive skill is the skill where the students should respond on written or oral discourse. This skill is like reading and listening. All skills are important but this research is focuses on writing for two reasons. First, written communication increases nowdays by the use of social media, email dan short message. Second, writing is complex skill so it should be trained carefully.

Writing is a process of exploration that offers benefits to students and content are teachers alike (Urquhart and McIver, 2005). As students write to make their ideas and comprehensible, they experience the fun of discovery, and so do their teachers. By writing, the students try to find ideas as the topic for writing, then, they arrange them to be quality writing. Writing enables the students to do exploration on their ideas so 
new ideas can be produced. In line with the idea, Meyers (2003) states that writing is a process of dicovering, assembling, delivering, reshaping, and revising ideas on paper. The ideas are processed to be able to understand by the readers. To support the ideas, linguistic skill also supports. If the ideas are not presented in good language, the readers may not get the ideas well (Marhaeni, 2005). Here, two aspects should be concerned by the writers to produce good writing.

Writing is often considered as the most difficult language skill to be learnt since its complexity makes it becomes difficult (Chakraverty and Gantum, 2001). Not only in the matter of linguistic ability, writing also involves various cognitive and creativity process. In cognitive process of writing, writing is viewed as a process of transaction between writer schemes which consist of variety of information (Ashman and Conway, 1997). In creative process of writing, the writing process is characterized by the insight of unique new ideas which is logically and uniquely arranged in writing (Marhaeni, 2005).

To make the students have good writing skill, innovative teaching methods should be applied (Brown, 2001). In modern education, writing instruction must be directed into constructivist perspective. Constructivism is an approach to learning that holds that people actively construct or make their own knowledge and that reality is determined by the experiences of the learner' (Elliott et al., 2000). It means that the students should involve directly during teaching and learning process. They should have chance to develop their writing skill. By doing so, they can have good writing skill.

To know the actual students' writing competency, an observation about teaching and learning process and students record was done for three weeks in SMAN 1 Sukasada. It was done in grade XI for academic year 2019/2020. From the observation, it was known that the students' writing skill was still low. It is just 65 in the average. It is lower than the established passing grade of 70. It means that there is a problem in students' writing skill because there is a gap between the expectation and the reality.

Further obervation was done to know the factors causing it. It was done from 17 of January until 17 February 2020. Based on the result of observation, teaching writing was done individually. There was less interaction found among students during teaching and writing process. Writing was also done at one or two sessions in which they should finish their writing product. The students are just given less time to produce writing. Therefore, it can be concluded that teaching writing with the method was still conventional (McCarthy and Anderson, 2000).

Ideally, teaching and learning process should be sociable meaning that there is interaction among students (Alt, 2016). This concept also must be applied in teaching writing context. The clever students to teach the low students so low students can learn from them. It is based on the theory of Zone of Proximal Development by Vygostksy (Nyikos and Hashimoto, 2011). The condition can lead the students to understand the writing topic more easily because they learn with their peer. It encourages the students to actively construct their knowledge by asking if they don't understand, searching materials to enrich their writing topic and analyzing materials for writing. It gives the students meaningful learning experiences (Lund and Hauge, 2011).

By comparing the teaching and learning writing process in reality and ideal one, it is urgent to do research for proving effectiveness of teaching method underlying on ZPD on writing competency, especially in teaching writing genres and eleventh grade 
students. It is because writing is a medium of communication which is increasingly done recently (Dharma and Adiwijaya, 2018). If the problem were not solved, it may be not good for the students' writing skill. For the reasons, doing experiment on teaching writing methods which have same characteristics as the ideal teaching method need to be done. It is to know its effect on writing skill so the result can be compared. Here, scaffolding technique is applied since its characteristics are same as the ideal one.

Scaffolding is a technique where the teacher helps the student master a task or concept that the student is initially unable to grasp independently (Lipscomb, Swanson $\&$ West, 2010). The teacher offers assistance with only those skills that are beyond the student's capability (Alibali, 2006). Here, the students are guided to achieve the goals of their learning. In the context of teaching writing, the goal is to produce quality writing product. The Student errors are expected, but, with teacher feedback and prompting, the student is able to achieve the task or goal (Ellis and Larkin, 1998). The students are given guidance to produce good writing product.

According to Benson (1997), scaffolding is actually a bridge used to build upon what students already know to arrive at something they do not know. If scaffolding is properly administered, it will act as an enabler, not as a disabler.The students can learn what they do not understand both from their teachers and friends. Scaffolding should be removed gradually and then removed completely when mastery of the task is demonstrated (Larkin, 2002). By doing so, the students can get feedback which can be used to improve their writing. It means that scaffolding can be a significant tool to contribute to the learning process because it assists students to solve their learning problems (Zarandi and Rahbar, 2014).

The ideas of scaffolding is actually same as the zone of proximal development (ZPD) (Vygotsky, 1978). Vygotsky suggests that there are two parts of a learner's developmental level: the "actual developmental level" and the "potential developmental level". The zone of proximal development is "the distance between the actual developmental level as determined by independent problem solving and the level of potential development as determined through problem solving under adult guidance, or in collaboration with more capable peers". Here, the scaffolding can create interaction among students or teachers (Zhao and Orey, 1999).

One of the main benefits of scaffolded instruction is that it provides for a supportive learning environment (Hogan and Pressley, 1997). In a scaffolded learning environment, students are free to ask questions, provide feedback and support their peers in learning new material. When the teacher incorporates scaffolding in the classroom, the teacher becomes more of a mentor and facilitator of knowledge rather than the dominant content expert.This teaching style provides the incentive for students to take a more active role in their own learning (Kamberi, 2013). The students share the responsibility of teaching and learning through scaffolds that require them to move beyond their current skill and knowledge levels. Through this interaction, students are able to take ownership of the learning event. (Northern Illinois University, 2019).

Research on the area of Scaffolding Teachnique and writing had been done previously by some experts (Sari, 2018; Faraj, 2015; Oktavianus, 2016). The researchers do research in classical learning (offline) and focus on in grammatical and vocabulary aspects of writing. They discover that scaffolding is effective to be applied in writing. However, this current research investigates the effect of Scaffolding Technique on writing in online learning. In addition, five aspects of writing are 
investigate, namely : content and development, organization, grammatical structure, vocabulary, and mechanic.

By analyzing carefully the concept of scaffolding, theoretically it has positive effect on students' writing competency in online learning. It is based on assumption that scaffolding has nearly same characteristics as the ideal teaching and learning condition. Therefore, this research tries to prove emperically the effect of Scaffolding Technique on students' writing skill in online learning so that it can be used as source of information in creating better writing instruction and competency.

\section{METHODS}

This research is classified into experimental research. It means that there is treatment given. The population of this research was 168 eleventh graders of SMAN 1 Sukasada in the academic year 2020/2021. By using cluster random sampling, two classes (XI IBB 1 consisted of 31 students and XI IBB 2 consisted of 30 students) were selected. XI IBB 1 were as the experimental group and XI IBB 2 were as the control group. Because the number of the students were different, one student was deleted in XI IBB 1 so the number of the students in each class became same. Even though one student was deleted but they were still included in the treatment.Therefore, there 60 students were selected as sample. Then, they were give treatment for 4 meetings for each group. This research applied nonequivalent control group design in which there were two groups compared, namely: scaffolding technique and conventional technique. Scaffolding Technique was applied with steps : instructor does, class does, group does and individual does. Meanwhile, the steps of conventional technique were : explaining material, showing example, question and answer session, and writing. At the end of the treatment, both groups were given posttest to collect the students' writing competency. During treatment, observation was also done to get information about students' behaviour. The data of writing competency were collected by using performance test which was then scored by using analytical scoring rubric. Performance test was designed based on school syllabus and designed grand theory. The obtained data were analyze statistically with descriptive and inferential methods.

\section{FINDING AND DISCUSSION}

This research aims at investigating the effect of Scaffolding Technique on students' writing competency in online learning. to know it, two analysis were needed, descriptive and inferential. Descriptive analysis was done to describe the data as they were. It proved which group was better. Furthermore, inferential hypothesis was done to know the difference value whether it was significant or not. To know the effect, the result of hypothesis testing was confirmed to the descriptive analysis. The group which had higher value was the better group or it had significant effect.

Data description covered the calculation of mean and standard deviation. The calculation of the mean and central tendency used SPSS 16 for Windows and the result could be presented in Table 1 . 
Table 1. The Result of Mean and Standard Deviation Calculation

\begin{tabular}{ccc}
\hline Analysis & \multicolumn{2}{c}{ Groups } \\
\cline { 2 - 3 } & $\mathbf{A 1}$ & $\mathbf{A 2}$ \\
\hline Mean & 28.7 & 28.13 \\
Standard Deviation & 4.23 & 4.14 \\
\hline
\end{tabular}

Note : A1 = students' writing competency treated by using Scaffolding Technique A2 = students' writing competency treated by using convetional technique.

Based on Table 1, it can be concluded that the mean score of students' writing competency treated by using Scaffolding Technique (28.7) is higher than the mean score of students' writing competency treated by using conventional technique (28.13). Furthermore, standard deviation of students' writing competency treated by using Scaffolding Technique (4.23) is higher than the standard deviation of students' writing competency treated by using conventional technique (4.14). It means that the data of students' writing competency treated by using Scaffolding Technique is more heterogenuous than students' writing competency treated by using conventional techniqu. However, this result can not merely used to know the effect of Scaffolding. To know its significant effect, it should be followed into inferential analysis or hyphotesis testing.

Before hypothesis testing by using t-Independent test was done, there were 2 prerequisite test that had to be fulfilled, normality test of data distribution and homogeneity test of variance. All the calculations were dony by using SPSS 16 for Windows.

Normality test of data distribution was done by Kolmogorov-Smirnov formula which was available in SPSS software. The result of the calculation can be presented in Table 2.

Table 2. Summary of Normality Test

\begin{tabular}{cll}
\hline Source of Variance & \multicolumn{2}{l}{ Kolmogorov-Smirnov } \\
\cline { 2 - 3 } & Df & Sig. \\
\hline Scaffolding & 30 & 0.144 \\
Conventional & 30 & 0.200 \\
\hline
\end{tabular}

Based on Table 2, it was known that the probability value (Sig.) of teaching technique 1 (Scaffolding) was 0.144 and teaching technique 2 (conventioal) was 0.200. It means that all groups of data had probability value which were higher than 0.05 . therefore, it can be concluded that all groups of data were normal in distribution.

Homogeneity Test of Variance was done by using Levene's Test which was available in SPSS program. The result of calculation is presented in Table 3.

Table 3. The Result of Homogeneity Test of Variance

\begin{tabular}{ccccc}
\hline Source & Levene Statistic & df1 & df2 & Sig. \\
\hline Based on Mean & 0.037 & 1 & 58 & 0.848 \\
\hline
\end{tabular}

Based on Table 3, it is known the significance value (Sig.) of Based on Mean is 0.848. This value is higher than 0.05 ( $p>0.05$ ). It means that the variance between the 
two groups were homogenuous. Hence, the result of t-test in hypothesis testing can be ensured from variance between groups not in group.

Hypothesis testing was done to answer whether or not there was a significant difference among students' writing competency taught by using Scaffolding Technique and those taught by using conventional technique. Here, independent sample t-test was used. This formula was selected because there were two groups compared. The result of calculation can be presented in Table 4 .

Table 4. The Summary of Hypothesis Testing

\begin{tabular}{cc}
\hline Statistic & Value \\
\hline Mean Difference & 0.57 \\
Df & 58 \\
t & 0.518 \\
Sig. & 0.606 \\
Remark & Not Significant \\
\hline
\end{tabular}

Based on Table 4, it is known that $t$ value of 0.518 with the significance value of 0.606 which higher than 0,05 ( $p>0.05)$. It means that there is no significant difference in writing competency between the students taught by using Scaffolding Technique and those taught by using conventional technique. It means that Scaffolding Technique does not have significant effect on students' writing competency in online learning.

This research was done via online. It was done because of Covid 19 pandemic where the schools were closed and learning should be done in online mode. In online learning mode, this research has proven that Scaffolding Technique does not affect significantly on students' writing competency. Even though, the mean score of students' writing competency taught by using Scaffolding Technique is higher than those taught by using conventional technique, the difference was not significant. This result is different from the previous researches (Sari, 2018; Veerappan, Suan and Sulaiman, 2011; Faraj, 2015; Oktavianus, 2016; Hasan, 2018; Majid, Stapa and Keong, 2015; Vonna, Mukminatien and Laksmi, 2015; Sari, Suparman and Sinaga, 2018; Baradaran and Sarfarazi, 2011) proven that Scaffolding Technique has positive effect on students' writing skill in reguler classess.

This reserach proves that Scaffolding Technique does not have significant effect to be applied in teaching writing in online learning. Online learning should be applied because of pandemic of Covid 19. It makes the teachers or education stakeholders should quaickly prepare online learning. The online learning is predicted to be the main factor causing Scaffolding Technique does not affect significantly students' writing. The implementation of online learning, especially, in SMAN 1 Sukasada where the experiment was done had some problems, such as : lack of chance for collaboration, limitation of time in online learning, lack of guidance for the students, seriousness of the students and technical problems.

Through online learning, limited collaboration was occured. The collaboration was only between teacher and students. It was rarely occured the interaction between student and students because online learning platform does not allow the students to do that. Instead, collaboration in scaffolding is rellay needed as the way for sharing with each others. Through collaboration, the students learn as community. Furthermore, through collaboration in Scaffolding Technique, various problems can be understood 
and solved together (Belland, Glazewski and Richardson, 2008). It directs the students to build their communication skill in written form.

In the context of teaching writing, collaboration is needed to share their ideas with their classmates and teachers because writing is an on-going process (Marhaeni, 2005). In offline learning, the students can directly arrange their seat with their group members. In this group, they can share mutually their work with each other. However, it is hard in online learning because of the platform used. If the collaboration in writing is not occured, knowledge construction of writing might be slow down because less of feedback. By collaboration, the students can get ample feedback from their friends and teachers. Here, the concept of ZPD underlying scaffolding technique is occured (Benson, 1997).

Besides the less of collaboration, limitation of time in online learning is a factor causing Scaffolding Technique is less effective fo writing. By using Google Meet, research was only allowed to be done for 1 hour (60 minutes). It is because of the cost for internet cell. The researcher has limited time to develop learning activities which makes learning is done in hurry. In normal situation, the class is done for 90 minutes for each meeting. It is not match to the writing nature. Writing is productive language skill in which the students should produce something i.e writing product (Harmer, 2006). Marhaeni (2005) also states that writing needs ample time to be done because writing is on going process. It can not be done only in one session class.

Next, the students get lack of guidance during writing process. The key of Scaffolding is guidance from good ability persons (students and teacher) to low ability students so they fet with each other (Larkin, 2002). The guidance was mostly from the teachers with limited time. The limitation of guidance makes the students is hard to develop their ideas to be good writing. It is different from reguler class, the students can get guidance fully in each writing session time. Besides that, guidance can be given directly to the students and the teacher can show and explain directly the weaknesses or mistakes of the students' writing.

Furthermore, because learning is done from distance, it makes the students less serious to join the online learning. Based on the reseracher's observation during treatment, the students were less serious in joining the virtual class. The had less focus on learning process. Most of them less spirit to do activities both in treatment and control groups. Briefly, most of them join the class because of school rule and less of awareness that the learning process is for their knowledge development. It was frequently some students make off their video conference so that the researcher does not know what they are doing. Even, the students had been advised frequently, they still do the same things.

Lastly, technical problems are frequently occured. The problems are bad internet connectivity and internet cell owned by the students. Based on the information from the headmaster, the students in the school were mostly from removed areas so internet signal is hard. This problem is also recognized by the teacher. Even though they can join the class via online, unstable signal is frequently disturbed. Furthermore, most of the parents are from low and moderate economic level which makes them little bit hard to buy internet cell, especially in this covid 19 pandemic. If the parents do not give money for their children to buyinternet cell, of curse they can not join the online class. 


\section{CONCLUSION}

Based on the result of hypothesis testing, it can be concluded that there is no significant difference in writing competency between the students' treated by using Scaffolding Technique and those treated by using conventional technique. It has proven from the probability value (Sig.) of 0.606 which was higher than $0,05(p>0.05)$. The mean score of students' writing competency treated by using Scaffolding Technique (28.7) is higher than the mean score of students' writing competency treated by using conventional technique (28.13). even though the mean score of writing competency treated by using Scaffolding Technique is higher than the mean score of writing competency treated by using conventional technique, the difference is not significant. It means that Scaffolding Technique does not have significant effect on students' writing competency in the context of online learning.

Based on the implication and conclusion, three suggestions are given for the three parties. For the English teachers, they are suggested to overcome the technical problems relating to online learning in implementing scaffolding technique. Scaffolding Technique is not recommneded if the ideal condition required by scaffolding technique are not overcome yet. It is because it does not give positive effect on students' learning. Furthermore, the teachers are suggested to be creative in keeping students' spirit in online learning. This research has proven that the students are less serious during joining online learning. For the students are suggested to be serious in studying during online learning is applied. If they are not serious in joining the online class, the learning objectives might not be achieved. For other researchers, they are suggested to do further research relating to the implementation of Scaffolding Technique on writing competency in online learning because this research proves that Scaffloding Technique is less effective in online learning. The further researches are expected to conduct deeper study by considering other variables, such as : motivation, self-efficacy, learning style, etc.

\section{REFERENCES}

Alibali, M. (2006). Does Visual Scaffolding Facilitate Students' Mathematics Learning? Evidence from early algebra. http://ies.ed.gov/funding/grantsearch/ details.asp? ID=54

Alt, D. (2016). Students' Perceived Constructivist Learning Environment: Empirical Examples of the Comparison between FACET THEORY with Smallest Space Analysis and Confirmatory Factor Analysis. European Journal of Psychological Assessment. DOI: 10.1027/1015-5759/a000358.

Ashman, A.F and Conway, R.N.F. (1997). An Introduction to Cognitive Education: Theory and Application. London: Routledge

Baradaran, A and Sarfarazi, B. (2011). The Impact of Scaffolding on the Iranian EFL Learners' English Academic Writing. Australian Journal of Basic and Applied Sciences. 5(12): 2265-2273. 
Belias, D., Labros, S., Nikolaos, K., Maria, K and Atanakios, K. (2003). Traditional Teaching Methods vs. Teaching Through The Application of Information and Communication Technologies in the Accounting Field: Quo Vadis? European Scientific Journal. 9(28): 73-101.

Belland, B.R., Glazewski, K and Richardson, J.C. (2007). A Scaffolding Framework to Support the Construction of Evidence-Based Arguments among Middle School Students. Educational Technology Research and Development 56(4). DOI: 10.1007/s11423-007-9074-1

Benson, B. (1997). Scaffolding (Coming to Terms). English Journal. 86(7): 126-127.

Brown, H. D. (2001). Teaching by Principles: An Interactive Approach to Language Pedagogy. White Plains: Addison Wesley Longman.

BSNP. (2012). Laporan BSNP. Jakarta : Depdiknas

Cakraverty, A. and Gautum K. (2001). Dynamic of Writing. Available at http://exchanges.state.gov/forum/vols38/no3/pp22.htm

Dharma, I.P.S and Adiwijaya, P.A. (2018). The Effect of Problem Based Learning and Self-Assessment on Students' Writing Competency And Self-Regulated Learning. SHS Web of Conferences 42, 00036. Available at https://doi.org/10.1051/shsconf/20184200036

Elliott, S.N., Kratochwill, T.R., Littlefield Cook, J. \& Travers, J. (2000). Educational Psychology: Effective Teaching, Effective Learning (3rd ed.). Boston, MA: McGraw-Hill College.

Ellis, E. S and Larkin, M. J. (1998). "Strategic Instruction for Adolescents with Learning Disabilities". In B. Y. L. Wong (Ed.), Learning about learning disabilities (2nd ed,585-656). San Diego: Academic Press

Faraj, A.K.A. (2015). Scaffolding EFL Students' Writing through the Writing Process Approach. Journal of Education and Practice. 6(13): 131-141

Harmer, J. (2006). The Practice of English Language Teaching. Cambridge: Pearson Longman

Hasan, M. (2018). Impactof Motivational Scaffolding on the Acquisition of Writing Skillsin L2 Situation. International Journal of Humanities and Social Science Invention (IJHSSI). 7(12): 39-45

Hogan, K., \& Pressley, M. (Eds.). (1997). Scaffolding Student Learning: Instructional Approaches and Issues. Cambridge, MA: Brookline. 


\section{PRASI JuRnal Bahasa, SENI, DAN PENGAJARANNYA}

VOL. 16 | No. 01 | June 2021

ISSN: Print 1693-6124 - Online 2614-1116

Undiksha| DOI: http://dx.doi.org/10.23887/prasi.v16i01.31152 | https://ejournal.undiksha.ac.id/index.php/PRASI

Kamberi, L. (2013). The Significance of Teacher Feedback in EFL Writing for Tertiary Level Foreign Language Learners. Procedia-Social and Behavioral Sciences. DOI: $10.1016 /$ j.sbspro.2013.01.241

Larkin, M. (2002). Using Scaffolded Instruction to Optimize Learning. Arlington, VA: ERIC Clearinghouse on Disabilities and Gifted Education. (Retrieved July 25, 2020 from ERIC at EBSCOhost, ERIC No. ED. 474 301).

Lipscomb, L., Swanson,J and West, A. (2010). "Scaffolding" In M. Orey (Ed) Emerging Perspectives on Learning, Teaching, and Technology. Available: http://projects.coe.uga.edu/epltt

Lund, A. \& Hauge, T. E. (2011). 'Changing Objects in Knowledge-Creation Practices' in S. Ludvigsen, A. Lund, I. Rasmussen \& R. Säljö (eds.) Learning Across Sites: New tools, Infrastructures and Practices. London: Routledge, 206-221.

Majid,A.H., Stapa,S.H and Keong, Y.C. (2015). Blended Scaffolding Strategies Through Facebookfor Learning and Improving the Writing Process and Writing Performance. International Conference on Social Sciences \& Humanities (ICOSH-UKM2O12)

Marhaeni, A.A.I.N. (2005). Pengaruh Assessment Portfolio dan Motivasi Berprestasi dalam Belajar Bahasa Inggris terhadap Kemampuan Menulis dalam Bahasa Inggris. Unpublished Dessertation: Proram Pascasarjana Universitas Negeri Jakarta

McCarthy, J.P and Anderson, L. (2000). Active Learning Techniques Versus Traditional Teaching Styles: Two Experiments From History And Political Science. Innovative Higher Education. 24(4): 279-294

Meyers, A. (2003). Composing with Confidence: Writing Effective Paragraphs Essays. New York:Addison Wesley Longman Inc.

Northern Illinois University. (2019). Instructional Scaffolding to Improve Learning. Spectrum. Available at www.facdev.niu.edu

Nyikos, M and Hashimoto, R. (2011). Constructivist Theory Applied to Collaborative Learning in Teacher Education: In Search of ZPD. The Modern Language Journal. 81(4): 506-517. Available at https://doi.org/10.1111/j.15404781.1997.tb05518.x

Oktavianus, H. (2016). The Use of Scaffolding Technique to Teach Recount Text Writing. Journal of Research Universitas Tanjung Pura.

Sari, D.S., Suparman, U and Sinaga, T. (2018). The Effectiveness of Scaffolding Technique on Students' Writing Analytical Expository Text. Publised Research by University of Lampung 
Urquhart, V and McIver, M. (2005). Teaching Writing in the Content Areas. Virginia: ASCD

Veerappan, V A/L., Suan, W.H and Sulaiman, T. (2011). The Effect of Scaffolding Technique in Journal Writing among the Second Language Learners. Journal of Language Teaching and Research. 2(4): 934-940

Vonna, Y., Mukminatien, N., and Laksmi, E. 2015. The Effect of Scaffolding Techniques on Students' Writing Achievement. Jurnal Pendidikan Humaniora. $3(1): 227-233$

Vygotsky, Lev. (1978). Mind in Society. London: Harvard University Press.

Zarandi, S.Z. A and Rahbar, B. (2014). Enhancing Speaking Ability through Intervening Scaffolding Strategies. Theory and Practice in Language Studies. 6(11): 2191-2195. Available at http://dx.doi.org/10.17507/tpls.0611.17

Zhao, R. And Orey, M. (1999). The Scaffolding Process: Concepts, Features, and Empirical Studies. Unpublished manuscript. University of Georgia. 